\title{
Children Born of War ${ }^{1}$
}

\author{
INGVILL C. MOCHMANN \\ CENTRAL ARCHIVE FOR EMPIRICAL SOCIAL RESEARCH \\ UNIVERSITY OF COLOGNE, GERMANY
}

\section{Resumen}

Este artículo ofrece una visión introductoria desde el novedoso campo de investigación de "Niños nacidos de la guerra". Se trata de niños y niñas nacidos durante y después de conflictos y guerras habiendo sido su padre miembro del enemigo, fuerzas aliadas o fuerzas de paz y su madre una ciudadana local. A menudo, los niños y niñas nacidos de la guerra son estigmatizados y discriminados en su propio país y sus intereses y derechos particulares eludidos en situaciones de postconflicto.

En este artículo se presenta una categorización de los niños nacidos de la guerra y algunos de los resultados del proyecto de investigación realizado sobre niños de la Segunda Guerra Mundial. Por último, se explora la situación internacional y judicial de estos niños así como las pautas posibles de ayuda dirigidas a éstos y sus madres.

Palabras Clave: niños nacidos de la guerra, estigmatización, discriminación, Segunda Guerra Mundial

\begin{abstract}
This paper gives a short introduction into the rather new research field of 'Children born of war'. These are children who are born during and after conflicts and wars were the father has been a member of an enemy, allied or peacekeeping force and the mother a local citizen. 'Children born of war' are often stigmatised and discriminated in their home country and their particular interest and rights are overlooked in post-conflict situations. This paper presents different categories of children born of war and some results from research projects on children from Second World War are presented. Finally, the international and juridical situation of children born of war are discussed and possible guidelines to assist mothers and children introduced.
\end{abstract}

Keywords: children born of war, stigmatisation, discrimination, Second World War

\footnotetext{
1 This article is based on a presentation at the workshop "Juventud Embotellada", University of Alicante in 2006 and it was a part of the monograph published from this seminary in 2007. For more recent developments in this research field and further publication see: http://www.childrenbornofwar.org
} 


\section{Introduction}

In addition to military consequences wars often have major effects on the civil population. Particularly, children and young people belong to the most exposed and vulnerable groups suffering both during and after military conflicts. Based on the general definition given by Article 1 of the UN Convention on the Right of the Child, a child will in the following refer to persons under the age of 18 (cf. UN Convention on the rights of the child, 1989).

In this presentation, I will discuss a special category of war-affected children, the so-called "war children" or "children born of war". The suffering of these children often starts after the war has formally ended. War children are children who receive a stigma as a result of being born by women who had a relationship with enemy or allied soldiers, peacekeeping personnel or children born as a result of politicised violence/rape used as sexualised war strategy. In the following several aspects of the situation of war children will be presented in order to emphasise the dimension of the topic and thus make clear the need for national and international policies to support the rights of these children.

Of course, all children are usually affected by wars in several different ways. They can be affected as civilians, both physically, and psychologically as well as emotionally. Physically they can be affected for example through the lack of food, water and medical supply, and injuries. Psychologically they can be long life traumatised by having been exposed to bombings and fighting and emotionally affected, for example, by having family member directly involved in the war or having lost family members in the war. They might have had to leave home town or even country, having being separated from parents etc.

Children can also be directly involved in the war, for example, as member of the army, serving as soldiers or by having another occupation in the forces not directly involved in the fighting. UNICEF estimates that at any given time, up to 300,000 children globally are being used in armed groups and forces in a variety of roles, including as combatants, cooks, porters, messengers, spies and for sexual purposes (UNICEF 2006).

It should be emphasised that it is not the aim of this presentation to make any evaluation of which children affected by war are worst off. Often, the consequences are similar for all the children; they are exposed to hunger, poverty and violence, losing normal childhood and schooling which again have lifelong individual consequences and also immense collective consequences at the societal level. Thus, when focusing on "children born of war" here, this is because these children are seldom considered or heard of, and I would like to use this opportunity to share with you some knowledge we have about the war children. In the following, I will thus focus on some historical, legal and political aspects of the situation of children born of war as well as the global dimension of the topic, hopefully clarifying why this is not a marginal issue, but one which should be taken seriously both nationally as well as internationally. 


\section{Who are the children born of war}

The "War and Children Identity Project" (WCIP) defines war children as "a child that has one parent that was part of an army or peace keeping force and the other parent a local citizen where the weight is on the stigma these children can be subject to as a result of their background (WCIP 2006). WCIP focuses on:

- Children who receive stigma as a result of being born by women who had a relationship with foreign soldiers, peacekeeping soldiers or allied forces.

- Children born as a result of sexualised violence/ rape used as war strategy.

Children born of war might be categorised in four main types: children of enemy soldiers, children of soldiers from occupational forces, children of child soldiers and children of peacekeeping forces.

Children of enemy soldiers: These children are fathered by foreign soldiers who are located in the country or region and clearly defined as enemies such as German soldiers in Norway, Denmark, Netherlands, France, Russia etc. during WWII or Bosnian Serb Army in Bosnia-Herzegovina during the war in former Yugoslavia 1991 to 1995 and US soldiers in Vietnam. An example of a child fathered by an enemy soldier is Anni Frid, one part of the popular group ABBA, who was born in Norway as a child of a Norwegian woman and a German soldier. She thought her father had died during the war, but a German fan got her in contact with him, and they finally met in 1977 (see Grieg, 2001:55ff.)

Children of soldiers from occupational forces: In this case the soldiers can be seen as enemies or allied, depending on the view of the local population. The allied forces occupying Germany in the post WWII years were for example in the population by some conceived as saviours and by others as enemies. In the case of Canadian troops in Great Britain or the Netherlands or US troops on Iceland, these were allied troops. Nevertheless, a liaison between local women and participants of the allied forces was often not accepted in the community and both mothers and children were stigmatised (cf. Ericsson and Simonsen 2005:44). The famous musician Eric Clapton, for example, is son of a Canadian soldier from Montreal and a British woman. He never met his father. Children of Canadian soldiers in Europe were often referred to as "War leftovers" (Grieg, 2001:20).

Children of child soldiers: In recent years, the topic of children born by child soldiers has reached the public agenda. According to News from the Office of the special Representative of the Secretary General for children and Armed Conflict an estimated 25.000 children, of whom 7.500 are girls have been abducted by the Lord's Resistance Army (LRA) in Uganda since the start of the conflict, some 1000 are "child mothers" who conceived while in captivity (UN News Centre, 2006). This implies that in Uganda alone more than 1000 babies can be assumed to have been born from girl soldiers. Considering that girls are involved in many other wars and conflicts around the world such as the Democratic Republic of Congo (DRC), Sierra Leona and Indonesia, it becomes clear that this is not a marginal problem, 
particularly when also taking into account that the number may be assumed to be even higher as many girls probably will not tell because of shame and not wanting to be stigmatised. And the children themselves - at least in most ongoing conflicts are still too young to raise their voice.

Children of peacekeeping forces: The issue of sexual exploitation and abuse arose end 2004 with the revelation that UN peacekeepers had engaged in such practices in the Democratic Republic of Congo (DRC). Some victims were abandoned orphans who were often illiterate and Secretary-General Kofi Annan immediately instituted a "policy of zero tolerance". As part of further efforts by the United Nations to enforce its "zero tolerance" policy on sexual exploitation and abuse, a draft strategy ( $\underline{\mathrm{A} / 60 / 877})$ on assistance and support to victims of such behaviour by UN staff and related personnel was prepared. The War and Children Identity Project (WCIP) was invited together with other non-governmental organisations (NGO's) to participate in the elaboration of the draft policy paper. We are of course very pleased to see that our arguments were heard and that the final draft forwarded to the General Assembly explicitly mentions children fathered by UN personnel. The "Draft United Nations policy statement and draft United Nations comprehensive strategy on assistance and support to victims of sexual exploitation and abuse by United Nations staff or related personnel" issued June 5, 2006 states that (UN, A/60/877:5):

6. The United Nations commits to providing assistance and support to three different categories of persons: (a) "complainants"; (b) "victims"; and (c) children born as a result of sexual exploitation and abuse by United Nations staff or related personnel. This commitment, however, in no way diminishes or replaces the responsibility of the individual perpetrators of acts of sexual exploitation and abuse"

Furthermore, the UN draft emphasises that: "Where there is credible evidence that a child has been fathered as a result of alleged sexual exploitation or abuse by a United Nations staff member or related personnel, the United Nations will assist the child, or his/her mother or guardian, in pursuing a claim to establish paternity or obtain child support, as outlined in the Comprehensive Strategy. The Organization will request the assistance of Member States in facilitating the pursuit of such claims." Also, the draft states that "the United Nations will establish a common funding mechanism to ensure the ready availability of funds so that assistance and support can be provided in a consistent and reliable manner. As the individual perpetrator bears the responsibility for acts of sexual exploitation and abuse, the United Nations, consistent with its Staff Regulations and Rules, will also assist in recovering money from perpetrators for payment towards assistance and support" (UN, A/60/877:5-6).

This UN policy might be of great importance to children born of war world wide as many of the social, political and economic rights and support systems addressed in the document would be applicable also in other war and conflicts. The UN policy might thus serve as best practise for personnel involved in other national and other international military and peacekeeping operations. 
Within each of the above described categories a further distinction might be drawn between children of prostitutes, children of mutual relationships and children of rape and sexual exploitation. It should be emphasised however that it is often difficult to clearly differentiate between what is exploitation and what is mutual in situation of wars and crisis. Children of prostitutes are for examples children of US soldiers based in the Philippines and women working in the entertainment industry. 25.000 children are estimated to have been fathered by US soldiers. Children of Filipino women and US soldiers were for example called Babay na sa - bye-bye to daddy (Grieg, 2001:11 \& 20). With regard to children of rape, particularly where mass rape was used as a military strategy of ethnic cleansing with the aim of impregnating women and girls, whole societies were left traumatised and the children become the symbol of the trauma the nation went through and society prefers not to acknowledge their needs (UNIFEM Report 2003, here in Carpenter 2005:4). The expressions of these children as "devil's children" (Rwanda), "children of shame" (East Timor), "monster babies" (Nicaragua) show how these children are perceived in the home country.

\section{How many children born of war exist}

It is not known how many children are born of war. Examples of this topic being raised can be traced back to World War I. About 15000 German children are expected to have been fathered by French and British soldiers from 1914-1918 (Grieg 2001:21). In Northern Europe where the German occupation force held records of children by German soldiers during the World War II the numbers are in tens of thousands.

Table 1: Estimates of Children by Military Personnel 1914-2000

\begin{tabular}{|l|c|c|}
\hline Country Father/Mother & Years of military presence & Numbers \\
\hline French and British/German & $1914-1918$ & 15000 \\
\hline Japanese/Korean & $1940-1945$ & 23000 \\
\hline American/British & $1941-1948$ & $22000+$ \\
\hline Canadian/British & $1940-1947$ & 8000 \\
\hline Canadian/Rest of Europe (mostly Dutch) & $1945-1946$ & Not known \\
\hline American/Rest of Europe & $1945-1946$ & 96000 \\
\hline American/West-German & $1945-1956$ & $14+$ \\
\hline British/Soviet & $1941-1945$ & $2000+$ \\
\hline UN(US)/Korean & 1950 & 12000 \\
\hline German/Norwegian & $1940-1945$ & 80000 \\
\hline German/France & $1941-1945$ & $10000-50000$ \\
\hline German/Dutch & $1941-1945$ & $2000+$ \\
\hline Austrian/US & $1945-1955$ & 52000 \\
\hline US/Philippines & $1965-1982$ & 5000 \\
\hline Indonesia/East-Timor & $1975-1999$ & 40000 \\
\hline US/Vietnamese & $1965-1975$ & $25000+$ \\
\hline Liberia & $1990-1998$ & $19000+$ \\
\hline Japanese/Chinese & $1945-1950$ & $2000-5000$ \\
\hline Rwanda & 1993 & 4000 \\
\hline Serb/Bonsian & 1992 & 25000 \\
\hline UNTAC/Cambodia & $1992-1997$ & \\
\hline
\end{tabular}

Source: a reduced version of the overview table published in Grieg 2001:8-9 
Some estimate that the number of American/Asian children born after the Vietnamese war numbers more than 100 000. Nevertheless, more than 500.000 war children might be assumed to live today (Grieg 2001:7). An overview with some of the estimates Kai Grieg from the War and Children Identity Project has collected from various sources is given in the Table 1.

Although Table 1 only presents some of the wars and conflicts where war children have been born and does not include children from more recent or ongoing conflicts it clearly points out that this is a global and timeless phenomenon.

\section{An example: Norwegian children fathered by German soldiers during WWII}

Before the civil war in former Yugoslavia started in the early 1990s, Europe had not been confronted with the question on how to deal with war children since the first post World War II years. However, this should not be confused with the fact that it still was and is a problem in European countries which have been involved in World War II either as civilians, occupants or allies. The silence surrounding the topic was - and still is - rather a consequence of fear and shame among the war children and their mothers and a whish to ignore and to taboo the topic at the political level.

"I grew up with the feeling of being the meanest thing ever born!" This quotation comes from a Norwegian conceived by a German soldier and a Norwegian woman when asked about its life at the age of 60. During the German occupation of Norway 1940-45 between 10.000 and 12.000 children were born by German soldiers and Norwegian women. Most of these children were a result of love affairs. Nevertheless, it proves that being conceived in a love affair, even if the mother tried to help the child and protect it, is not necessarily a ticket to a good life for these children. Research shows that many of the Norwegian war children have been discriminated and stigmatised. For example, analyses of register data show these children have poorer health, higher suicide rates, less education and income than other Norwegians from the same age cohort, even when compared to children of lone raising mothers (Ellingsen, 2004). Furthermore, the children were in the Norwegian population often considered enemies, with the worry - particularly in the first post-war WWII years that they might become a troop of marching, German friendly young adults who could become a threat to Norway in future (Ericsson and Simonsen 2005:46).

A questionnaire survey was carried out among 650 Norwegian war children in 1997 by Prof. Stein Ugelvik Larsen from the University of Bergen and his team ${ }^{2}$ in cooperation with the Norwegian war child organisation. The response rate was approximately $50 \%$. The net sample includes 336 respondents. The survey includes 250 questions about childhood, youth, parents, identity, school years, health etc.

\footnotetext{
2 The data have been collected and prepared by an international research group working on the research project "A comparative study on Danish, Norwegian and Dutch war children" under the leadership of the principal investigator Prof. Stein Ugelvik Larsen, Department of Comparative Politics, University of Bergen, Norway. Members of the group are Stein Ugelvik Larsen and Elna Johnsen, Norway, Arne Øland, Denmark, Ingvill C. Mochmann, Germany, and Monika Diedrichs, the Netherlands
} 
These children may not be representative for all war children, neither in World War II context nor in European or world-wide context. Nevertheless, the results may give us important information regarding the fate and life chances of a larger group of war children - between 50 and 60 years old at the time of the surveys - which go beyond the description of single life biographies.

This information may thus provide useful knowledge which both war children born today as well as in future may profit from. The same survey was in 2003 carried out also among about 400 Danish war children and 40 Dutch children fathered by German soldiers. Comparative analyses between these three countries are presently being carried out and may allow for some discussions regarding similarities and differences both at individual, local and national level (cf. also Mochmann and Larsen 2005).

The question of identity and the importance to know the biological parents are one of the essential topics of the survey. Results on the question why it was important for the respondents to find - in most cases - the father show that more than half of the respondents wanted to know if there were "any similarities with regard to looks, character and talents" and wanted to know whether they "look like their father". Less than three per cent wanted to find their father in order to "know about income and fortune with the aim of requiring a part of it."

With regard to the question how the war child sees the fact that its mother had relationship with the enemy 55,1\% answer that their "mother experienced her big love with my father and that was the most important" and more than one third think "the Norwegian society should by shameful about they way they treated my mother". In the Norwegian case the state has acknowledged that it has failed to secure the rights of the Norwegian war children after WWII was over and decided in 2005 to give the children - 60 years after the war - a small financial compensation (for details on the compensation see Justissekretariatene 2006).

\section{How to assist children born of war}

The War and children Identity Report 2001 emphasises five ways in which the children born of war can be assisted:

- Provide material support to mothers and children

- Information campaigns to prevent discriminations

- Assistance in claiming compensation from fathers

- Assistance in claiming compensations from governments

- Assistance in locating father (and mothers) of children born of war

In addition, further steps must be implemented at national and international level to secure the rights of children born of war. There must be more focus on the protection and interest of the child. i.e. clear laws and regulation must exist regarding birth registration, citizenship, access to facilities such as school and health system. Liberia is one of the few countries whose constitution recognises children 
born of war as citizens, whereas children of Bosnian refugee mothers in Croatia were sometimes denied citizenship (see Carpenter 2005:7). The rights of children born of war must be anchored in national and international conventions and treaties. At the local level their mothers must be helped to return to their family and community - reintegrated into society. It must be followed up at the international level and methods to sanction violators must be installed, such as the procedures outlined in the UN draft A/60/877 presented above. The rights of mothers and children must be incorporated in national and international legislation in such a way they exist independent of a conflict because in peace agreements the rights of "enemy" children will never play a crucial role on the agenda - their rights must therefore be clarified prior to conflicts.

\section{Conclusion}

In conclusion, children born of war and their special needs and problems must be taken seriously. As long as there are conflicts and war children belonging to different sides will be born, whether from love affairs, exploitation or rape and being fathered by soldiers, peacekeeping forces, humanitarian workers etc. We have examples from all over the world since WWII like Amerasians in Vietnam, UN children in Cambodia etc, German children conceived by Russian soldiers and German mothers in captivity who spent their first years behind military fences midend 1940 etc., children conceived by allied forces in Germany after WWII, children born by US fathers and Icelandic women during WWII etc. In cases where ethnic and race differences between the child born and the population, the stigma was often even worse as the conditions of the conception were impossible to hide. In earlier wars and conflicts only $5 \%$ of the civilians were affected by the war, today the number has increased to $90 \%$ : rapes as terror, ethnic cleansing etc. used as war strategy has obviously increasingly become a strategy of war and this problem may also be assumed to maintain and maybe even increase. The challenge lies in finding a procedure which secures the rights of these children without simultaneously increasing their stigmatisations making them even more vulnerable or even putting their lives at risk. 


\section{References}

Carpenter, Charli (ed.), Protecting children born of sexual violence and exploitation in conflict zones: existing practice and knowledge gaps, Graduate School of Public and International affairs and Ford Institute for Human Security, University of Pittsburgh, 2005.

Ellingsen, Dag: En registerbasert undersökelse, Statistics Norway, Rapport Nr. 2004/19, Oslo.

Ericsson, Kjersti and Simonsen, Eva: Krigsbarn i fredstids, Universitetsforlaget, 2005.

Grieg, Kai: The War Children of the World, War and Children Identity Project (WCIP), Bergen, 2001

Justissekretariatene: War children' can apply for compensation, http://www.justissekretariatene.no/English.html, 2006.

Mochmann Ingvill $C$ and Larsen, Stein Ugelvik: Kriegskinder in Europa. In: Aus Politik und Zeitgeschichte, Nr. 18-19/2005, p. 34-38. (Danish version was published in Rödder, Nr. 1\&2, 2005, p. 23-29 and a Norwegian version in Røtter, Nr. 3, 2005, p. 23-28).

United Nations: Convention on the Rights of the Child, 1989.

UNICEF Press Centre: Criminal charge in child soldier case a milestone in protecting children http://www.unicef.org/media/media 31753.html, March 18, 2006.

UN News Centre: UNICEF seeks urgent funds to aid nearly 1 million children displaced by war in Uganda, http:/ / www.un.org/apps/news/story.asp?NewsID=18494\&Cr=uganda\&Cr $1=$ May 16, 2006.

United Nations: Draft United Nations policy statement and draft United Nations comprehensive strategy on assistance and support to victims of sexual exploitation and abuse by United Nations staff or related personnel, June 5th 2006.

War and Children Identity Project" (WCIP), http://www.warandchildren.org/project\%20history.html (access December 4, 2006). 